\title{
Transculturality in "Das Märchenbuch der heiligen Nächte der Javanerland" (1915) by Max Dauthendey
}

\author{
Lilawati Kurnia ${ }^{1}$ \\ \{purplemoon08@gmail.com ${ }^{1}$ \} \\ ${ }^{1}$ Universitas Indonesia, Jakarta, Indonesia
}

\begin{abstract}
Abstarct. Borrowing various aspects of literature and culture outside Europe is one othe the many research in travel literature. Max Dauthendey (MD) is a writer and painter who traveled around the world and the second trip took him to Java. In his book, MD respond's to the encounter with "the other" is a keen observation of the folk tales, and he transferred these into his fairy tales with his own imagination. Through close reading of three MD tales, MD's point of view to the foreign culture will be revealde. This paper will shows that what MD wrote and displayed in the three fairy tales is the exotic Java and it is a conspicous attempt to appreciate the javanese folklore and nature. Java as an exotic place is integrated in the works and instead of adapting the stories which will be resulting in changing the media, MD took only some elements. Different approach to the loan is shown in this paper by applying transculturality as a method to read literary works that collaborating two cultures. Transculturality in MD's fairy tales is a process of reconfiguration of the elemnts from Java into his work and MD has shown a positive way of borrowing.
\end{abstract}

Keywords: transculturality, Java, fairy tale, Max Dauthendey, exotic

\section{INTRODUCTION}

Some motifs from javanese folktales are borrowed and rewrited into three fairy tales for a german girl by MD with the title "Das Märchenbuch der heiligen Nächte Javanerland". This paper will discuss how the loan on the micro level has become a new work of art and become an effectuated generic loan [1]. Not only that, the German-language literature is enriched with the works of German authors who write about countries outside Europe. Although the country which is now known as the Republic of Indonesia has not yet been established, some German writers have known the archipelago and some have visited it. One of the writers and painters was Max Dauthendey, he made two trips around the world. On the second trip he also visited the area which was still under the control of the Netherlands, namely Java. The book he wrote on Java was a promise he gave to Lore, his niece, a fairy tale that became a Christmas present. MD only managed to complete three fairy tales from the twelve tales he promised. The three story are, Geschichte des Beovogels (The Story of Beo the bird), Geschichte der weissen Schildkrote (The Story of the White Turtle), Geschichte des Wasserbuffels (The Story of The Waterbuffalo) [2]. The german writer MD was not the only german that has visited and live in 
the archipelago, in fact there were many of them that were brought by the East India Company or VOC as soldier or as a prominent officers.

Kurnia in her dissertation (2000,unpublished) has written about the arrival of Germans to the archipelago as both ordinary soldiers and governors-general of the VOC. Applying the notion of das Fremde or 'the other' in reading four novels about Indonesia, she contributes to the vast research of colonial imagery of Indonesia [3]. Kurnia also found that the images formed in the four novels she analyzed in her dissertation were images that showed ambiguity in the attitude of Europeans towards the archipelago and its inhabitants. On the one hand, the Dutch considered das Fremde as the object of conquest, on the other hand they could not avoid the awe they feel for the richness of culture and nature that stretched out in front of their eyes. In doing so the dutch formed the imagery of the colonial land and has developed a kind of hybrid culture known as 'mooie Indies'. Finding writings on Dauthendey that corresponds with the spirit of his time seems a bit difficult because he was seen as a poet of a rather flamboyant person and his writings considered as mirroring the sehnsucht in die Ferne or Fernweh (longing for the long journey). MD was described as out of the structure of his time, his writing could not be classified into the genre of early of the 20th century [4]. He has travelled to Asia in fulfilling a dream of an European imagery of an exotic place [5]. He was also looking for a refreshing view and re-entchatment of the world, escape from the europäische Müdigkeit (the fatigueness of Europe) and finding the strange, exotic world outside Europe [6]. The exotic Asia was a very fascinating for writers of the 19th and 20th century in Germany, using the elements of the literature they wrote many works. MD was also perceived by several researchers who wrote their dissertations on him, as a modern painters and MD uses various elements of modernity in his paintings, as so do his literary works, which look pluralistic and exotic like Gauguin's paintings [7]. That is the motivation of his journeys and the reason why his writings are more or less having a kind of 19th or early 20th century tourist gaze. There is a certain mode of literary borrowing from the East, which Abu er-Rub.et.al discuss in their book, that is a positive one which incorporated the genre or motivs into the story and also admitting the loan. On the other hand, some might use the loan and change the genre to the point of unrecognizable anymore without mentioning the source. This book also discuss on the term of transculturality which they promote as a new paradigm in the footprints of multiculturalism and interculturalism. This paper will shows how the exoticsm of Java enriched the tales but in turn also shows how MD's point of view to the people and land of Java.

\section{METHOD}

Transculturality, which is a method for analyzing three MD tales, is a method related to previous methods such as interculturality and multiculturalism. According to Abu-er-Rub et al. Transculturality is better suited to cultural studies because culture is understood as a dynamic and always interacting. Culture is also an important element because it underlies all interconnectivity and promotes understanding. Transculturality rejects the Eurocentric and superior mainstream assumptions, therefore one of the characteristics of transculturality is critical towards those monolithic views. In short, transculturality emphasizes the connectivity, even if there is a border, what is expected is border crossing so that it can be said that entanglement and hybridation are highlighted.

In reading the fairy tales, the exotic Java was highlighted, this in turn shows that even though Java was seen as an exotic land, the view is mild and positive.MD uses Java as an exotic thing to strengthen its fairy tale about Asia. Images that are formed positively like 
depicting java people were like chocolate, and suggesting that the chocolate walking on the street is not only to suggest the color but the sweetness of chocolate. Consequently, for young children to imagine that in Java all the people are brown and sweet could be fun. In addition, fairy tales that use typical java animals such as parrots, turtles and buffaloes are things that make tales become authentic and make imagery about java very beautiful. Moreover, MD also mentioned the habits of Javanese to chew bettlenut and sirih leaf. The mentioning of exotic fruits, coconuts, pepaja, also followed the pattern of exoticsm in all three tales. All elements showed here certainly have an exotic appeal because of the intense need to highlight the fairy tales as a work written from Java, but the exoticism is not for Java land but for German readers. So the exoticism is like a mere decoration. The exoticism found in these three fairy tales gives the feel of Java as an exciting and fantastic world because all three tell about Java folklore and belief in gods despite the existence of mainstream religions such as Islam and Christianity. Exotic Java also offers a variety of things that are different from Europe besides the natural environment, it can be seen MD's admiration for the local culture he encountered. In this case, Java is also a utopia for travelers from Europe in processing the story elements from the island of Java.

\section{RESULT AND DISCUSSION}

All the writings about Asia were initially linked to the travel literature genre, because Europeans came to Asia as travelers only. Urry writes about the tourist gaze, which is how the gaze is a process of destruction because local culture is reduced to commodities. The tradition that became the pillar of the local community became a mere spectacle because the locals wanted to fulfill the desire of tourists to enjoy exotic things and what was even more worrying was the sorting of traditions and local culture expression just to fulfill the needs of tourists so that other aspects would be forgotten and even to some point extinct. According to the Urry's tourist gaze [8], it is supported by the regional government and the travel business. In order to expand the tourism, many local government look for the folklore or tradition that will be wrapped and sold to tourist. Consequently the travel literature also use the tradition or the narrative aspects of the folklore to enrich and make use the narrative elements. We can also find this aspect in MD fairy tales which took the folklore or myth of the javanese and used them to enchance his tales.In line with this fact, the name Java is in the title of his book and also mentioned in the introduction of the three stories has the function of confirmation of the utopian 'the other .

Like any literary work the fairy tale also has leitmotif, this word comes from german language. Leitmotive is a narrative element that repeats throughout a work of literature. Originating from the music, motifs in literature may come in the form of reoccurring imagery, language, structure, or contrasts [9]. The development of motifs in a work of literature often contributes to mood and/or theme. The motif in his fairy tale is the search for a beautiful queen by the narrator and later after he has met the queen of south seas, he is seeking for something more ideal. This leitmotiv oft can be found in fairy tales, which also accentuate the courage and prowess of the hero. On the contrary with the image of a hero, MD potray a hero, in this case the narrator to be someone who is not stand out in the crowd. The hero does not posses any super power or skill, he is just like MD a fellow traveller. In this sense, Maria Noelle $\mathrm{Ng}$, which discussed by Keck [10] explained the reasons for the sympathic view of MD towards Java or Southeastasia, it is the Zeitgeist of the fin de siecle in Europe. MD's interest to go abroad was more due to will of exploring instead of gaining and an urge to travel. 
The narrator explains also that in the end all the amazing thing he experience was only in his dream. In this way, MD have shown that he was trying also to educate his niece that all fairy tales were only story which we shared when we were young. In the tales the narrator has transformed himself into a parrot, a white turtle, and water buffalo. When he became a parrot, he met with Emperor Java (maybe MD meant the Sultan of Java) who wanted to kill him but he has learn as a parrot he must also praise the people who give him meals. Meanwhile in the story of the white turtle he was carried to the vast ocean on the back of the white turtle. In this case, Java folklore or myth such as the Ratu Laut Selatan (Queen of the South Sea) are also incorporated in the fairy tale about white turtles. In this case, Java folklore or myth such as the Ratu Laut Selatan (Queen of the South Sea) are also incorporated in the fairy tale about white turtles. After seeing the beauty of the Queen, the narrator decided to be her King, but this decision is wrong because he has to stayed forever in the South Sea. In the third tale, MD even potrays the surrounding and environment in Garut, the town he lives. He mentioned the hotel or guesthouse he lived, the Papandajan, also some rivers. These exotication of the place he could not leave is an attempt to promote the place itself [11]. He begann the tale with the keen observation of the water buffalo, the helper of all peasants in Javaland. After seeing the beautiful javanese Princess, the narrator now hae another wish. He wants to be able to hear the grass grows (das Gras wachsen hören) [12] is a saying in Germany with the meaning of somebody who is knowledgeable or someone who has all the informations. MD in his third tale wanted to give Lore the lesson on how to use the time wisely. Instead of looking for treasure or gold, it is better to learn and obtain the knowledge of other country.

Another point of view in looking into the travel literature is the Fernweh or the far woe, most of the travel literature in the 19th century and beginning of the 20th century deal with this motif. Fernweh is not only a longing for lands far away, to be able to go out in the seas, but also a kind of projection for an ideal condition [13]. However, MD as a tourist who is not an ordinary tourist. This could be read in the introduction when MD explained to Lore that the Menschenfresser or cannibals that they are not exist anymore, even though if MD had to go into the forest all the cannibals are already gone. In this sense, MD has the urge to travel far or Reiselust and that is why also he is experiencing Heimweh, the urge to go home all the same [14]. Klawiter shows us how the poet MD although could not speak and understand japanese language during his stays there, MD could writes at least 8 poems [15]. However, when MD was in Java, he did not have the same difficulty because he has a guide and could obtain all the folklore there. Through close reading it can be seen that MD sympathizes with Java, he even noticed some natural damage phenomena as he wrote about the Bird of Paradise. The number of this beautiful bird has decreased because it is often being trapped and people have taken the beautiful feathers and sold to Europe to decorate European women's hats. Likewise MD launched a criticism of the input of modernity through railroads that could erode local traditions and culture. In doing so, MD has shown us, that borrowing motifs and backgrounds from java is done positively by MD.

\section{CONCLUSION}

The writings about countries outside Europe, especially Asia, use imagery about Asia that circulated at that time. This happened because readers in Europe expected exotic reading and liked things that were different from the situation in Europe at that time. Therefore, European authors then borrowed motives from Asia to build their stories, and on this borrowing on MD are positive because MD clearly mentions the origins of the motives in their tales. The formed transculturality in the three tales consequently shows us how MD uses the best variety of 
information and knowledge about Java. A fairly clear picture of fruits, plants and traditions and habits of the java people is given correctly without reducing or adding unnecessary things. Although the three fairy tales are clearly made in anticipation of Christmas, and we can see unusual grooves found in fairy tales such as brave heroes or animals that have the power to change people's destiny, but these three fables can describe the situation of the city Garut and the surrounding environment are very comfortable for MD. Similarly MD has paid attention to local traditions and customs and placed them in fairy tales. Thus, it can be said that the three fairy tales do provide information and knowledge about java people without making it look like a fantastic story.

\section{REFERENCE}

[1] Abu-er-Rub, Laila, Chistiane Brosius et.al. Engaging Transculturality:Conceps, Key Terms, Case Studies (Engaging With...). Routledge. 2019.

[2] Dauthendey, Max. Das Märchenbuch der heiligen Nächte in Javanerland. https://gutenberg.spiegel.de/autor/max-dauthendey-118. 2009.

[3] Kurnia, Lilawati, Citra Indonesia di dalam Empat Novel Jerman Abad 20. Disertasi belum diterbitkan. FIB-UI. 2000. http://lib.ui.ac.id/detail?id=83548

[4] Orlick, Manfred. Ein Umtriebene und fast vergessener Dichter mit einem malerischen Blick. Zum 100. Todestag von Max Dauthendey. https://literaturkritik.de/dauthendeylichter-dunkeln-dauthendey-wildgaense-flug-ein-umtriebiger-fast-vergessener-dichtermit-einem-malerischen-blick,24843.html.2018. 2016.

[5] Wolfdietrich, Rasch (Ed.). Dichterische Prosa um 1900. Tübingen: Max Niemezer. 2017

[6] Zaharia, Michaela. Exotischer Weltbilder in der deutschsprachigen Literatur von Max Dauthendey bis Ingeborg Bachmann. Hamburg: Kovac.2009

[7] Rduch, Aleksandra E. Max Dauthendey. Gaugin der Literatur und Vagabund der Boheme, mit unveröffentlichten Texten aus dem Nachlass. Frankfurt am Main : Peter Lang. 2013

[8] Urry, John. Tourist Gaze. Sage Publication. 2002

[9] Wilpert, Gero. Sachwörterbuch der Literatur. Krönert Verlag. 2001

[10] Keck, L. Stephen. "Three Exotic Views of Southeast Asia:The Travel Narratives of Isabella Bird, Max Dauthendy, Ai Wu, 1850-1930 by Maria Nelle Ng". Journal of Southeast Asian Studies Vol. 35, No. 2 (Jun, 2004), pp. 357-359 (3 pages). Cambrigde University Press. 2004.

[11] Börner, Klaus. "Was die Paradiesvogel erzählen. Max Dauthendey "javanische Märchen”. In: Literatur und Regionalität. Ed Anselm Maler. Frankfurt am Main: Peter Lang. 1997.

[12] Fracia, Luisa. Das Grass Wachsen Hören. Die spirituelle Fähigkeiten des Körpers Nymphenbürger. 2003.

[13] Parry, Christoph and Liisa Voßschmidt (Ed.). Kennst Du das Land...? Fernweh in der Literatur. Iudicium. 2010.

[14] Winter, Ines. Fernweh, Heimweh, Reiselust:Eine Auswandererfamilie Unerwegs in Südostasien. United PC. 2013.

[15] Klawiter, Anna. The poetization of analphabethism. Fictionalisation of a foreign and indecipherable writing of Max Dauthendey, Bernhard Kellermann, and Henri Michaux. 2013. 